\title{
Measurement of Setschenow Constants for Six Hydrophobic Compounds in Simulated Brines and Use in Predictive Modeling for Oil and Gas Systems
}

\author{
Aniela Burant, Gregory V. Lowry, and Athanasios K. Karamalidis* \\ Department of Civil and Environmental Engineering, Carnegie Mellon University, \\ Pittsburgh PA, 15213 \\ ${ }^{*}$ Corresponding Author: \\ Address: 118J Porter Hall Civil \& Environmental Engineering Carnegie Mellon University \\ 5000 Forbes Avenue, Pittsburgh, PA 15213-3890
}

Phone Number: 412.268 .1175

Fax Number: 412.268 .7813

Email address: akaramal@andrew.cmu.edu

\begin{abstract}
Treatment and reuse of brines, produced from energy extraction activities, requires aqueous solubility data for organic compounds in saline solutions. The presence of salts decreases the aqueous solubility of organic compounds (i.e. salting-out effect) and can be modeled using the Setschenow Equation, the validity of which has not been assessed in high salt concentrations. In this study, we used solid-phase microextraction to determine Setschenow constants for selected organic compounds in aqueous solutions up to 2 - $5 \mathrm{M}$ $\mathrm{NaCl}, 1.5-2 \mathrm{M} \mathrm{CaCl}_{2}$, and in $\mathrm{Na}-\mathrm{Ca}$ binary electrolyte solutions to assess additivity of the constants. These compounds exhibited log-linear behavior up to these high $\mathrm{NaCl}$ concentrations. Log-linear decreases in solubility with increasing salt concentration were observed up to 1.5 - $2 \mathrm{M} \mathrm{CaCl}_{2}$ for all compounds, and added to a sparse database of $\mathrm{CaCl}_{2}$ Setschenow constants. Setschenow constants were additive in binary electrolyte mixtures. New models to predict $\mathrm{CaCl}_{2}$ and $\mathrm{KCl}$ Setschenow constants from $\mathrm{NaCl}$ Setschenow constants were developed, which successfully predicted the solubility of the compounds measured in this study. Overall, data show that the Setschenow Equation is valid for a wide range of salinity conditions typically found in energy-related technologies.
\end{abstract}




\section{Introduction}

Many energy-related technologies, such as carbon capture, utilization, and storage (CCUS); enhanced oil recovery (EOR); and unconventional oil and gas extraction; and desalination technologies (e.g. reverse osmosis) produce highly saline waters containing dissolved organic compounds (e.g. petroleum and synthetic hydrocarbons). The solubility of organic compounds in water usually decreases with increasing salinity. Therefore, assessing the risks of mobilization of organics from brine and/or $\mathrm{CO}_{2}$ leakage from geologic storage formations (e.g. leakage from Sleipner gas field in the North Sea (Monastersky, 2013)) or migration of produced waters from unconventional oil and gas reservoirs into freshwater aquifers require reliable ways of predicting the solubility of a number of different apolar and semi-polar organic compounds in brines. The composition of the brines mentioned above is typically dominated by dissolved alkaline and alkali metal chlorides (e.g. $\mathrm{NaCl}, \mathrm{CaCl}_{2}$ ) which sometimes can reach total dissolved solids concentration of 400,000 mg/L (DOE/NETL-2003/119, 2003; Shaffer et al., 2013). The effect of dissolved salts on the aqueous solubility of organic compounds, called the "salting-out" effect, is typically modeled by the empirical Setschenow Equation (Burant et al., 2013; Sechenov, 1889) (Eqn. 1). The model is empirical, with Setschenow constants ( $K_{s}^{i, k}$ Eqn. 1) determined experimentally for each organic compound as well as each salt of interest.

$$
\log \left(\frac{\gamma_{w}^{\text {sal }}}{\gamma_{w}^{D l}}\right)=\log \left(\frac{S_{w}^{D l}}{S_{w}^{\text {salt }}}\right)=\log \left(\frac{K_{1}^{\text {sal }}}{K_{1}^{D I}}\right)=K_{s}^{i, k}[\text { salt }] \quad \text { Eqn. } 1 .
$$

In this equation, $\gamma_{w}^{D I}$ is the activity coefficient of an organic compound in deionized water (DI water), $\gamma_{w}^{\text {salt }}$ is the activity coefficient of the organic compound in water at the salt concentration of interest, $S_{w}^{D l}$ is the aqueous solubility of the organic compound in DI water, $S_{w}^{\text {salt }}$ is the aqueous solubility of the organic compound at the salt concentration of interest, $K_{1}^{\text {sal }}$ is a partitioning coefficient of an organic compound between water and another phase (air, solid, for example) at the salt concentration of interest, $K_{1}^{D l}$ is the partitioning coefficient of an organic compound between water and another phase at the salt concentration of interest, $K_{s}^{i, k}$ is the Setschenow constant of the organic compound ( $i$ 
) for the specific salt $(k)\left(\mathrm{M}^{-1}\right)$, and $[$ salt $]$ is the concentration of salt (M). The presence of salt causes an increase in the activity coefficient of the organic compound in the saline solution relative to the DI water. This corresponds to a decrease in aqueous solubility and an increase in partitioning from water. In mixed salt solutions the Setschenow constant is determined based on the mole fractions of the salts present:

$$
K_{s}^{\text {mied }} \cong \sum_{k} K_{s}^{i, s a l, k} \cdot x_{k} \quad \text { Eqn. } 2 .
$$

where $K_{s}^{\text {mixed }}$ is the Setschenow constant of the mixed electrolyte system, $K_{s}^{i, s a l t, k}$ is the Setschenow constant of organic compound $(i)$ in a single electrolyte solution $(k)$, and $x_{k}$ is the mole fraction of each type of salt solution comprising the mixture. The $K_{s}^{\text {mixed }}$ can then be applied to Eqn. 1, replacing $K_{s}^{i, k}$, to predict the aqueous activity coefficient, aqueous solubility, or partition coefficient of a compound in the mixed electrolyte solution.

The ability of the Setschenow Equation to predict the solubility for many organic compounds has been confirmed only for aqueous solutions with salt concentrations up to 1 $\mathrm{M} \mathrm{NaCl}$ (Xie et al., 1997). Data for the solubility of organic compounds for high salinity $\mathrm{NaCl}$ and $\mathrm{CaCl}_{2}$ solutions is scarce. In addition, there are only 19 reported $\mathrm{CaCl}_{2}$ Setschenow constants, despite the fact that $\mathrm{CaCl}_{2}$ is a major component of oil and gas reservoir brines (Kharaka and Hanor, 2003). The additive nature of the salting-out effect (Eqn 2) has only been demonstrated for benzene and naphthalene at moderate ionic strengths (John E Gordon and Thorne, 1967; McDevit and Long, 1952).

Reported aqueous solubility data are available for benzene, toluene, ethylbenzene, and the xylene isomers (BTEX) up to $5 \mathrm{M} \mathrm{NaCl}$ (Keeley et al., 1991, 1988). However, these compounds are relatively small and monopolar, and more data on representative compounds from different classes of organic compounds are needed to assess the validity of the Setschenow Equation over a broader range of salt concentration, and to determine if Setschenow constants determined at low salt concentration can be extended to brines $(\geq 1$ M). The Setschenow Equation may not be valid for larger and monopolar/apolar or polar 
organic compounds, i.e. organic compounds with more than one aromatic ring or organic compounds capable of hydrogen bonding interactions (Eisen and Joffe, 1966; Janado et al., 1983; Jochmann et al., 2006; Lee, 1997; Meranda and Furter, 1974). For example, Janado et al., 1983 found that the Setschenow Equation did not predict the salting-out effect for naphthalene and biphenyl in aqueous NaSCN and KSCN solutions, which exhibited both salting-out and then salting-in effects, while benzene only exhibited salting-out behavior. Although deviations from the Setschenow Equation are not common for solutions of moderate salt concentration (i.e. up to $1 \mathrm{M}$ ), Whitehouse, 1985 observed deviations from the Setschenow Equation for 1,2-benzanthracene, a $\mathrm{PAH}$, in concentrations of $\mathrm{NaCl}$ up to seawater (Whitehouse, 1985). Since there are $\sim 193$ reported $\mathrm{NaCl}$ Setschenow constants (Endo et al., 2012; Ni and Yalkowsky, 2003), the extension of the previously measured Setschenow constants up to high salt concentrations would be ideal, since additional experimental data for derivation of Setschenow constants would not need to be collected. However due to lack of reliable solubility measurements at high salinity it is uncertain if the Setschenow Equation can be used to accurately predict the aqueous solubility of a variety of organic compounds at high salt concentrations expected in brines (Endo et al., 2012).

The additivity of the Setschenow constants was confirmed for benzene and naphthalene, over a range of different salt compositions with different anions and cations, and for a several hydrophobic organic compounds up to seawater salinity (Eganhouse and Calder, 1976; Rossi and Thomas, 1981; Sutton and Calder, 1975). The additivity of Setschenow constants for mixed electrolytes (Eqn 2) has not been confirmed with extensive data collection, and never for high salinity fluids (i.e. with higher than seawater salinity).

Avoiding experimental determination of new Setschenow constants is desirable, especially for $\mathrm{Ca}^{2+}$ as data are especially sparse. Modeling approaches to predict Setschenow constants have had moderate success using correlation with molar volume (Endo et al., 2012; Jonker and Muijs, 2010; Long and McDevit, 1952; McDevit and Long, 1952; Xie et al., 1997) and octanol-water partitioning coefficients (Endo et al., 2012; Ni and Yalkowsky, 2003). Compounds with larger molar volumes tend to have higher Setschenow 
constants. In addition, apolar and monopolar compounds with high octanol-water partition coefficient $\left(\mathrm{K}_{\mathrm{ow}}\right)$ tend to have larger Setschenow constants than polar compounds. The first attempt to capture these trends in a model to predict $\mathrm{NaCl}$ Setschenow constants was obtained by regressing log Kow with measured $\mathrm{NaCl}$ Setschenow constants (Eqn. 3) ( $\mathrm{Ni}$ and Yalkowsky, 2003). This study showed a fairly good correlation $\left(n=101, R^{2}=0.772\right.$, reported standard error $=0.041$ ) between the predicted and experimental $\mathrm{NaCl}$ Setschenow constants. Log Kow is a good qualitative proxy for Setschenow constants, because both follow trends in size and polarity. However, Endo et al., 2012 could not reproduce this simple fit using different compounds. Rather, Endo et al., 2012 developed a polyparameter linear free energy relationship (pp-LFER), which incorporates Abraham solvation parameters to account for size and intermolecular interactions (Eqn. 4) to predict $\mathrm{NaCl}$ Setschenow constants $\left(n=43, R^{2}=0.83\right.$, reported standard deviation $\left.=0.031\right)$.

$$
\begin{array}{cc}
K_{s}^{i, N a C l}=0.040 \log K_{o w}+0.114 & \text { Eqn. } 3 \\
K_{s}^{i, N a C}=0.112-0.020 R_{2}-0.042 \pi_{2}-0.047 \alpha_{2}-0.060 \beta_{2}+0.171 V_{2} & \text { Eqn. } 4
\end{array}
$$

The coefficients in Eqn. 4 are the Abraham solvation parameters. The $R_{2}$ is the index of refraction of the organic compound, $\pi_{2}$ is the organic compounds polarizability, $\alpha_{2}$ is the hydrogen bonding acidity of the organic compound, $\beta_{2}$ is the hydrogen bonding basicity of the organic compound, and $V_{2}$ is the molar volume of the compound.

Wang et al., (2014) developed a similar pp-LFER using the Abraham solvation parameters, however for the prediction of $\left(\mathrm{NH}_{4}\right)_{2} \mathrm{SO}_{4}$ Setschenow constants. However, no models have been developed to predict Setschenow constants for $\mathrm{CaCl}_{2}$. However these will be needed to predict solubility of organic compounds in saline waters associated with CCUS and EOR.

The objectives of this work were (1) to determine whether reported Setschenow constants, measured at low salt concentration, are applicable to high salinity solutions (from $2 \mathrm{M}$ to $5 \mathrm{M} \mathrm{NaCl}$ and in the range of $1.5-2 \mathrm{M} \mathrm{CaCl}_{2}$ ); (2) to determine if Setschenow constants are additive for selected compounds in mixed electrolyte brines; and (3) to 
develop and test two respective LFER models for predicting $\mathrm{CaCl}_{2}$ and $\mathrm{KCl}$ Setschenow constants from $\mathrm{NaCl}$ Setschenow constants. The effect of salt on the aqueous solubility of the PAHs, naphthalene, fluorene, and phenanthrene, and of several heterocyclic sulfur compounds, thiophene, benzothiophene, and dibenzothiophene were studied for both $\mathrm{NaCl}$ and $\mathrm{CaCl}_{2}$ solutions. Data from this study and literature were used to train models that predict Setschenow constants in $\mathrm{CaCl}_{2}$ and $\mathrm{KCl}$ solutions from experimental values derived with $\mathrm{NaCl}$. In addition, data from the literature was used to train the $\mathrm{KCl}$ model. The last objective enables accurate prediction of largely unavailable $\mathrm{CaCl}_{2}$ and $\mathrm{KCl}$ Setschenow constants from the more often reported $\mathrm{NaCl}$ Setschenow constants determined in lieu of experimentation.

\section{Materials and Methods}

The estimation of Setschenow constants was completed using solid phase microextraction (SPME), followed with analysis of the adsorbed organic compounds using gas-chromatography coupled with a flame ionization detector (GC-FID). SPME, has been used in previous studies to measure Setschenow constants and has proven to produce consistent and accurate results (Endo et al., 2012; Jonker and Muijs, 2010). The Setschenow constants were estimated by linear regression of Eqn. 1, where differences in area count output from the GC-FID was used to represent the change in aqueous activity coefficient (Eqn 5).

$$
\log \left(\frac{A_{s a k}}{A_{D l}}\right)=K_{s}^{i, k}[\text { salt }] \quad \text { Eqn. } 5
$$

In this equation, $A_{\text {salt }}$ is the area count from the SPME fiber after salt exposure, and $A_{D I}$ is the area count from the SPME fiber before salt exposure (in deionized water). In this method the salt does not change the activity, or the ability of the SPME fiber to absorb the hydrophobic compounds studied here (Endo et al., 2012).

One measurement was made per vial after salt addition and all replicate measurements were done in separate samples. For accurate measurements of Setschenow constants, two criteria have to be met (Jonker and Muijs, 2010). First, the aqueous solubility of the organic compound in solution cannot be exceeded, as this would cause an introduction of a third 
phase (which would cause a decrease in organic compound partitioning to the fiber). Second, depletion of the organic compound in solution due to sorption of the organic compound on the fiber must be minimized. Further analysis supporting that these assumptions are met is provided in Appendix B.

2.1 Materials. Thiophene ( $\geq 99.5 \%)$, benzothiophene (98\%), dibenzothiophene $(98 \%)$, fluorene (98\%), and phenanthrene (98\%) were obtained from Sigma Aldrich. Naphthalene (99\%) was obtained from Acros Organics. Sodium chloride (ACS Grade, 299\%) and anhydrous calcium chloride (ACS Grade, >96\%) were obtained from Fisher Scientific. The organic compounds were dissolved in pesticide grade acetone. Glassware was silanized overnight with 90 vol\% toluene (ACS Grade, $\geq 99.5 \%$, Fisher Scientific) and 10 vol\% dichlorodimethylsilane (99+\%, Acros Organics). The vials used for analysis were cleaned with DI water, methanol (ACS grade $299.8 \%$ ) and methanol, and a detergent rinse (Sparkleen, Fisher Scientific). After cleaning, they were dried at $105{ }^{\circ} \mathrm{C}$ for $>1$ hour. Three different types of SPME fibers (Sigma Aldrich) were used to measure PAHs; $100 \mu \mathrm{m}$ polydimethylsiloxane (PDMS) for naphthalene, fluorene, and dibenzothiophene; $7 \mu \mathrm{m}$ and $100 \mu \mathrm{m}$ PDMS fiber for phenanthrene; and $85 \mu \mathrm{m}$ polyacrylate (PA) for thiophene, and benzothiophene.

2.2 Methods. Between $35-39 \mathrm{~mL}$ of deionized water (Barnstead nanopure 18.2 $\mathrm{M} \Omega-\mathrm{cm}$ ), depending on the target salt concentration, was added to a $40 \mathrm{~mL}$ silanized glass vial, capped with PTFE-lined silicone septa, and wrapped in aluminum foil to prevent exposure to light. Target organic compounds were dissolved in pesticide grade acetone, and $20 \mu \mathrm{L}$ of the solution was added to the water. At this concentration of acetone ( $0.2 \mathrm{vol} \%)$, acetone will not act as a co-solvent and alter the solubility of the target compounds in solution (Schwarzenbach et al., 2003) Solution masses and dilutions were performed gravimetrically $( \pm 0.001 \mathrm{~g})$. A PTFE stir bar was added to each vial to assist achieving faster equilibrium times by stirring. The SPME fiber was exposed directly to the water for a predetermined amount of time; larger compounds typically took longer to reach equilibrium with the SPME fiber (See Appendix A), which was determined by conducting an uptake curve. After the SPME fiber was desorbed by direct injection in the GC inlet, salt was weighted gravimetrically ( $\pm 0.001 \mathrm{~g}$ ), the vial was uncapped, and the salt was poured into 
the vial, after complete mixing on the stir plate, the fiber was exposed to the solution once again. One set of vials (in triplicate) was used with one prescribed salt addition. The time required for each compound to reach equilibrium between the dissolved phase and the fiber increased with increasing salt concentration, so the time the fiber was exposed to the aqueous solution was increased accordingly to ensure equilibrium was obtained at each salt concentration (See Appendix A). After equilibration, the stainless steel part of the needle was rinsed with DI water, and wiped off to remove the salt from the surface, to protect the GC-FID and prolong fiber's life. The fibers were finally desorbed in the GC inlet for quantification of the increased amount of organic compound on the fiber. All experiments were conducted at room temperature $\left(23 \pm 2^{\circ} \mathrm{C}\right)$. The Setschenow constant is not responsive to small changes of room temperature (May et al., 1978).

The organic compound analysis was carried out with a GC-FID (Agilent 6890A) equipped with a split/splitless injector. Helium at $23 \mathrm{~mL} / \mathrm{min}$ was used as the carrier gas. The inlet temperature was set at $250^{\circ} \mathrm{C}$ for $100 \mu \mathrm{m}$ PDMS, at $320^{\circ} \mathrm{C}$ for the $7 \mu \mathrm{m}$ PDMS, and at $280^{\circ} \mathrm{C}$ for $85 \mu \mathrm{m}$ PA fibers. The fiber was desorbed for two minutes in the inlet. The column used was $30 \mathrm{~m} \times 320 \mu \mathrm{m} \times 0.25 \mu \mathrm{m} 5 \%$ phenyl-95\% methyl (HP-5, J\&W Scientific). The oven program varied across analytes. The FID was kept at a temperature of $320^{\circ} \mathrm{C}$.

The $\mathrm{NaCl}$ salt concentrations measured were $1 \mathrm{M}, 2 \mathrm{M}, 3 \mathrm{M}, 4 \mathrm{M}$, and $5 \mathrm{M} \mathrm{NaCl}$ for thiophene and naphthalene; $1-4 \mathrm{M} \mathrm{NaCl}$ for benzothiophene, $1-3 \mathrm{M} \mathrm{NaCl}$ for phenanthrene and $1-2 \mathrm{M} \mathrm{NaCl}$ for dibenzothiophene and fluorene. The $\mathrm{CaCl}_{2}$ salt concentrations measured were $0.25 \mathrm{M}, 0.5 \mathrm{M}, 0.75 \mathrm{M}, 1 \mathrm{M}, 1.5 \mathrm{M}$, and $2 \mathrm{M}$ for thiophene, benzothiophene, and dibenzothiophene, 0.25 - 1.5 $\mathrm{M}$ for fluorene and phenanthrene. The mixed electrolytes systems were for thiophene and fluorene at ionic strengths of $1.5 \mathrm{M}$ $\left(0.75 \mathrm{M} \mathrm{NaCl}, 0.25 \mathrm{M} \mathrm{CaCl}_{2}\right), 2.0 \mathrm{M}\left(0.5 \mathrm{M} \mathrm{NaCl}, 0.5 \mathrm{M} \mathrm{CaCl}_{2}\right), 2.5 \mathrm{M}(0.25 \mathrm{M} \mathrm{NaCl}, 0.75 \mathrm{M}$ $\mathrm{CaCl}_{2}$ ), and $5 \mathrm{M} \mathrm{(2} \mathrm{M} \mathrm{NaCl}_{1} 1 \mathrm{M} \mathrm{CaCl}_{2}$ ) (only for thiophene). These were chosen because they are the relevant concentrations of oil and gas reservoirs. Concentrations of $2 \mathrm{M} \mathrm{NaCl}$ represent typical median total dissolved solids concentrations for some oil and gas reservoirs (Benko and Drewes, 2008; Gregory et al., 2011). The Setschenow constants reported here were estimated from ordinary least-squares (OLS) linear regressions of log change in area against salt concentration, as in Equation 5, performed in MATLAB using the 
Statistics Toolbox [Matlab R2013A]. The estimated standard errors of the Setschenow constants multiplied by two were also calculated in MATLAB and are reported with each Setschenow constant.

2.3 Modeling. The single parameter linear free energy relationships (sp-LFERs) for predicting $\mathrm{KCl}$ or $\mathrm{CaCl}_{2}$ Setschenow coefficients from $\mathrm{NaCl}$ coefficients were developed from OLS linear regression using data from literature and measured in this study. The model was validated and parameter uncertainty was evaluated using repeated k-fold crossvalidation $(\mathrm{CV})$. In this method the data was randomly divided into k-blocks (i.e. a set of Setschenow constants) of nearly equivalent size. The linear model was fit (or "trained") using k-1 blocks of data while one block of Setschenow constants was left out. The predictive accuracy (reported here as RMSE) of the model was then tested using these excluded data. For this study the data were split into $\mathrm{k}=10$ partitions. To account for the small sample size (which may lead to large variance or high bias), the 10 -fold CV was repeated 30 times. These permutations yielded $300 \mathrm{sp-LFER} \mathrm{parameter} \mathrm{estimates,} \mathrm{which}$ were averaged and reported. As with regression, CV was performed in MATLAB.

\section{Results and Discussion}

\subsection{NaCl Setschenow Constants}

The Setschenow constants for selected compounds were determined using the SPME method (Figure 1 and Table 1). Previously reported $\mathrm{NaCl}$ Setschenow constants for the PAHs are found in Table 1, while thiophenes have no reported $\mathrm{NaCl}$ Setschenow constants. The standard error of those estimates for $K_{s}^{i, N a C l}$ were low $\left(0.008-0.043 \mathrm{M}^{-1}\right)$, and values are comparable to previously reported measurements of Setschenow constants determined at lower salt concentration, for the PAHs (Jochmann et al., 2006; Jonker and Muijs, 2010). Triplicate measurements per salt concentration are shown in Figure 1 for each organic compound. Measurements made at higher salt concentrations required longer time to reach equilibrium, also consistent with previous observations using the SPME method (Jochmann et al., 2006).

Setschenow constant values from this study are comparable to previously reported measurements of Setschenow constants determined at lower salt concentration.(Jochmann 
et al., 2006; Jonker and Muijs, 2010) The magnitude of the $\mathrm{NaCl}$ Setschenow constants for the PAHs followed expectations based on their molar volumes and their previously reported Setschenow constants, with phenanthrene having the largest salting-out parameters, followed by fluorene and naphthalene. This did not occur for the thiophenes. It was expected due to its higher molar volume that dibenzothiophene would have a higher $\mathrm{NaCl}$ Setschenow constant. However, benzothiophene $\left(K_{s}^{i, N a C l}=0.230 \mathrm{M}^{-1}\right)$ has a larger in magnitude $\mathrm{NaCl}$ Setschenow constant than dibenzothiophene $\left(K_{s}^{i, N_{a} C}=0.213 \mathrm{M}^{-1}\right)$. A review of $\mathrm{NaCl}$ Setschenow constant data shows that there is only a slight correlation of Setschenow constants with molar volume $\left(\mathrm{R}^{2}=0.513\right)$. A discussion on the $\mathrm{NaCl}$ Setschenow constant of dibenzothiophene can be found in Section 3.4.

In addition, the $\mathrm{NaCl}$ Setschenow constants measured at low salt concentration for the thiophenes also extend up to higher salt concentrations. This shows that the Setschenow Equation for the hydrophobic compounds reported here are log-linear up to 2 - $5 \mathrm{M} \mathrm{NaCl}$. NaCl Setschenow constants that have been previously measured for other organic compounds can be extrapolated up to higher $\mathrm{NaCl}$ concentrations, the implications of which are discussed in Section 3.6. 

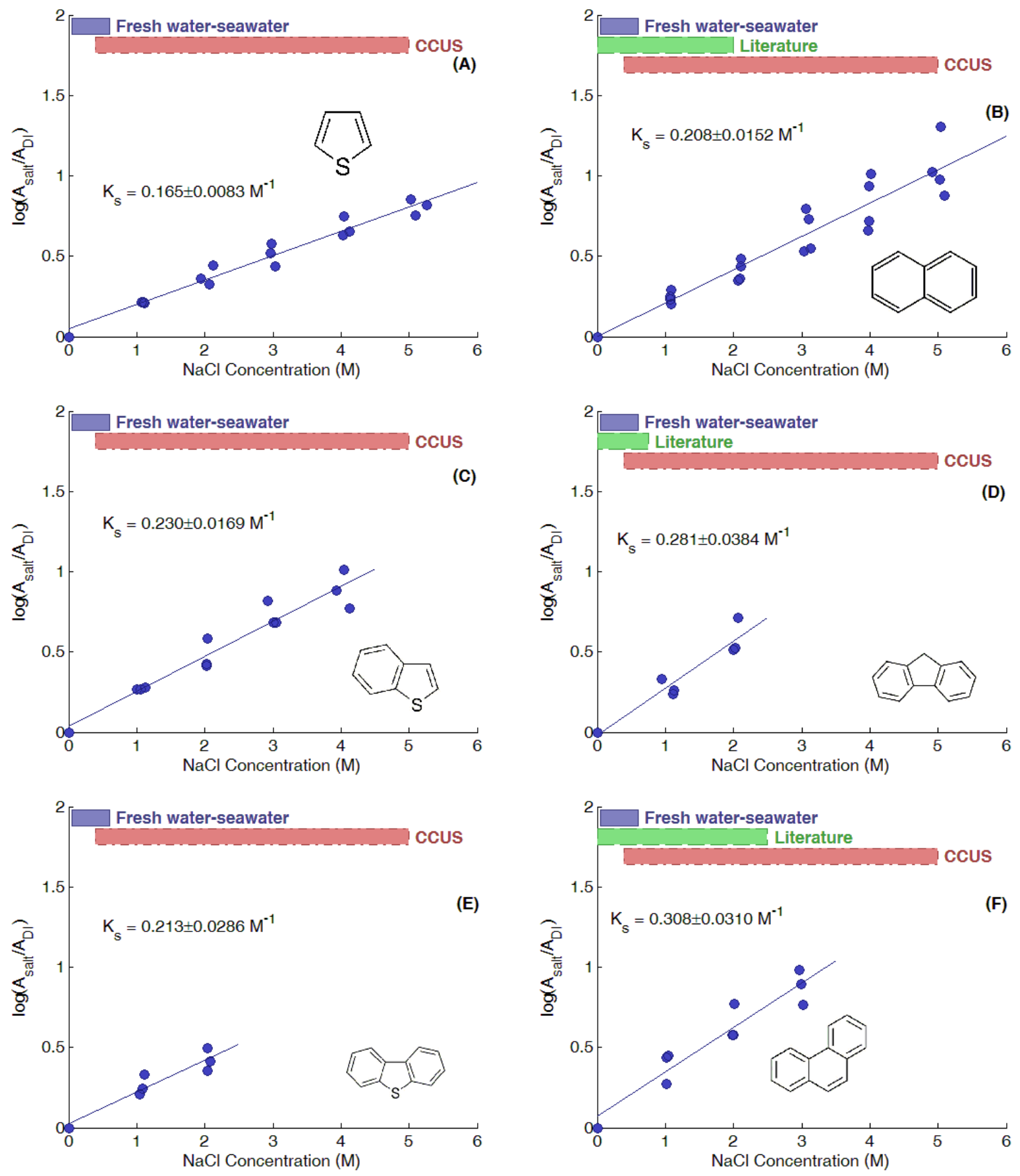

Figure 1. The effect of salt addition (i.e. $\log \left(A_{\text {salt }} / A_{D I}\right)$ ) of selected organic compounds onto the SPME fiber as for A) thiophene, B) naphthalene, C) benzothiophene, D) fluorene, E) dibenzothiophene, and F) phenanthrene. Colored bars represent ranges of salt concentrations for previously reported Setschenow constants (green); seawater (blue bars) and for CCUS conditions $0.6 \mathrm{M}-5 \mathrm{M} \mathrm{NaCl}$ (this study, red bars). The valid range of 
$\mathrm{K}_{\mathrm{s}}$ estimates are indicated by the black regression line. Reported constants $\left(\mathrm{K}_{\mathrm{s}}\right)$ are the regression mean $\pm 2 \cdot \mathrm{SE}$.

Table 1. Summary of previously reported experimentally determined Setschenow constants for $\mathrm{NaCl}$, data produced in this study for $\mathrm{NaCl}$ and $\mathrm{CaCl}_{2}$ for hydrocarbons used in this study.

\begin{tabular}{|c|c|c|c|c|}
\hline $\begin{array}{c}\text { Organic } \\
\text { Compound }\end{array}$ & $\begin{array}{l}\text { Reported } \mathrm{NaCl} \mathrm{K} \\
\qquad\left(\mathrm{M}^{-1}\right)\end{array}$ & $\begin{array}{l}\text { Range of } \\
\text { NaCl } \\
\text { Concs. (M) } \\
\text { (reported) }\end{array}$ & $\begin{array}{c}\mathrm{NaCl} \\
\text { Setschenow } \\
\text { Constants } \\
\text { from this } \\
\text { study }\left(\mathrm{M}^{-1}\right)\end{array}$ & $\begin{array}{c}\mathrm{CaCl}_{2} \\
\text { Setschenow } \\
\text { Constants } \\
\text { from this } \\
\text { study }\left(\mathrm{M}^{-1}\right)\end{array}$ \\
\hline \multirow{7}{*}{ Naphthalene } & $\begin{array}{c}0.213 \\
\text { (May et al., 1978) }\end{array}$ & $0-0.75$ & \multirow{7}{*}{$\begin{array}{r}0.208 \\
\pm 0.015\end{array}$} & \multirow{7}{*}{$\begin{array}{c}0.32 \\
\text { (John } \\
\text { Edward } \\
\text { Gordon and } \\
\text { Thorne, } \\
\text { 1967) }\end{array}$} \\
\hline & $\begin{array}{c}0.22 \\
\text { (John E Gordon } \\
\text { and Thorne, } \\
\text { 1967) }\end{array}$ & $0-2$ & & \\
\hline & $\begin{array}{c}0.23 \\
\text { (Hashimoto et al., } \\
1984 \text { ) }\end{array}$ & $0-1$ & & \\
\hline & $\begin{array}{c}0.255 \\
\text { (John Edward } \\
\text { Gordon and } \\
\text { Thorne, 1967) } \\
\end{array}$ & $0-2$ & & \\
\hline & $\begin{array}{c}0.26 \\
(\text { Paul, 1952) } \\
\end{array}$ & $0-0.02$ & & \\
\hline & $\begin{array}{c}0.303 \\
\text { (Eganhouse and } \\
\text { Calder, 1976) } \\
\end{array}$ & $0-0.5$ & & \\
\hline & $\begin{array}{c}0.62 \\
\text { (Schwarz, 1977) }\end{array}$ & $0-0.5$ & & \\
\hline Fluorene & $\begin{array}{c}0.267 \\
\text { (May et al., 1978) }\end{array}$ & $0-0.75$ & $\begin{array}{l}0.281 \pm \\
0.038^{\mathrm{a}}\end{array}$ & $\begin{array}{c}0.362 \\
\pm 0.043^{\mathrm{d}} \\
\end{array}$ \\
\hline \multirow{7}{*}{ Phenanthrene } & $\begin{array}{c}0.24 \\
\text { (Schwarz, 1977) }\end{array}$ & $0-0.5$ & \multirow{7}{*}{$\begin{array}{c}0.308 \\
\pm 0.029 \mathrm{~b}\end{array}$} & \multirow{7}{*}{$\begin{array}{c}0.373 \\
\pm 0.03^{\mathrm{d}}\end{array}$} \\
\hline & $\begin{array}{c}0.269 \\
\text { (Whitehouse, } \\
1985,1984)\end{array}$ & $0-0.6$ & & \\
\hline & $\begin{array}{c}0.272 \\
\text { (Hashimoto et al., } \\
1984 \text { ) }\end{array}$ & $0-1$ & & \\
\hline & $\begin{array}{c}0.275 \\
\text { (May et al., 1978) }\end{array}$ & $0-0.75$ & & \\
\hline & $\begin{array}{c}0.287 \\
\text { (Aquan-Yuen et } \\
\text { al., 1979) }\end{array}$ & $0-2.5$ & & \\
\hline & $\begin{array}{c}0.38 \\
\text { (Jonker and Muijs, } \\
2010) \\
\end{array}$ & $0-0.45$ & & \\
\hline & $\begin{array}{c}0.387 \\
\text { (Eganhouse and } \\
\text { Calder, 1976) } \\
\end{array}$ & $0-0.5$ & & \\
\hline Thiophene & $\mathrm{N} / \mathrm{A}$ & $\mathrm{N} / \mathrm{A}$ & $\begin{array}{r}0.165 \\
\pm 0.008 \\
\end{array}$ & $\begin{array}{r}0.295 \\
\pm 0.017 \\
\end{array}$ \\
\hline Benzothiophene & $\mathrm{N} / \mathrm{A}$ & $\mathrm{N} / \mathrm{A}$ & $\begin{array}{c}0.230 \\
\pm 0.015^{\mathrm{c}} \\
\end{array}$ & $\begin{array}{c}0.289 \\
\pm 0.018 \\
\end{array}$ \\
\hline Dibenzothiophene & $\mathrm{N} / \mathrm{A}$ & $\mathrm{N} / \mathrm{A}$ & 0.213 & 0.217 \\
\hline
\end{tabular}


aDetermined using data up to $2 \mathrm{M} \mathrm{NaCl}$

$\pm 0.03^{\mathrm{a}}$

$\pm 0.025$

bDetermined using data up to $3 \mathrm{M} \mathrm{NaCl}$

cDetermined using data up to $4 \mathrm{M} \mathrm{NaCl}$

dDetermined using data up to $1.5 \mathrm{M} \mathrm{CaCl}_{2}$

*Measured in a different study.

\section{2 $\mathrm{CaCl}_{2}$ Setschenow Constants}

Calcium chloride Setschenow constants were measured for all of the compounds in this study, with the exception of naphthalene, which has a previously reported $\mathrm{CaCl}_{2}$ Setschenow constant $\left(K_{s}^{i, C_{a} C_{2}}=0.322 \mathrm{M}^{-1}\right.$ ) (John Edward Gordon and Thorne, 1967) (Table 1 and Figure 2). The intercepts do not go precisely through the origin in Figure $2 B$-E, due to experimental error, which is taken into account when the $\mathrm{CaCl}_{2}$ Setschenow constants are reported in Table 1. The $\mathrm{CaCl}_{2}$ constants, due to the fact that $\mathrm{Ca}^{2+}$ is a divalent cation, were higher than $\mathrm{NaCl}$ Setschenow constants for all of the compounds of interest in this study, and also in the literature (See section on modeling of $\mathrm{CaCl}_{2}$ Setschenow constants). In addition, all the exhibited salting-out effects for these compounds were log-linear up to 1.5 - $2 \mathrm{M} \mathrm{CaCl}_{2}$, showing that the previously reported $\mathrm{CaCl}_{2}$ constants can be used with confidence up to $\mathrm{CaCl}_{2}$ concentrations typical of oil and gas reservoirs. 

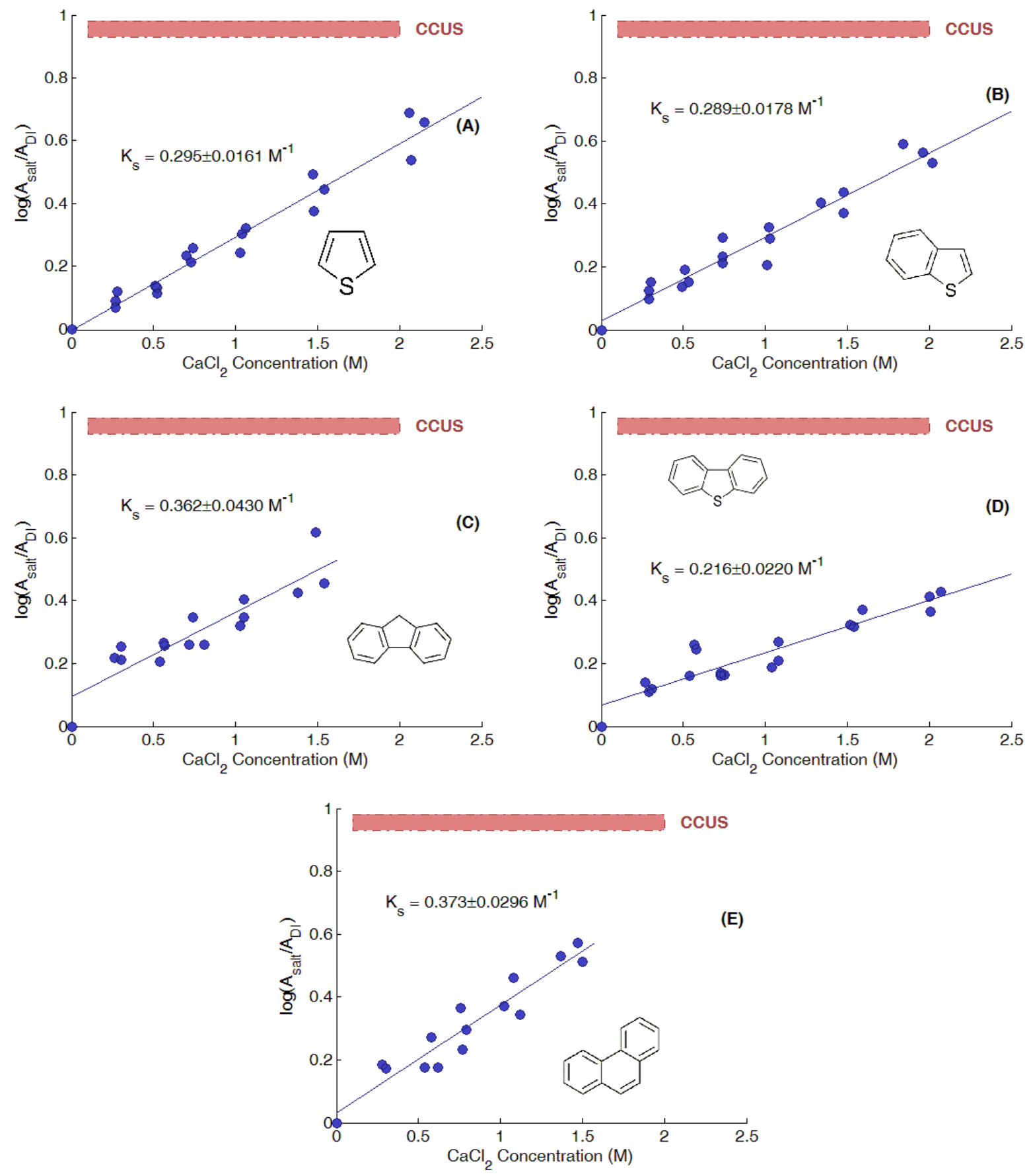

Figure 2. The salting-out effect (i.e. $\log \left(\mathrm{A}_{\text {salt }} / \mathrm{ADI}_{\mathrm{DI}}\right)$ of individual organic compounds onto the SPME fiber as a function of $\mathrm{CaCl}_{2}$ concentration (M) for A) Thiophene, B) Benzothiophene, C) Fluorene, D) Dibenzothiophene, and E) Phenanthrene. Red bars represent salt concentrations for Setschenow constants reported for: CCUS $0.1 \mathrm{M}-5 \mathrm{M}$ $\mathrm{CaCl}_{2}$ (this study). Reported constants $\left(\mathrm{K}_{\mathrm{s}}\right)$ are the regression mean $\pm 2 \cdot \mathrm{SE}$. 


\subsection{Mixed Electrolytes}

Thiophene and fluorene were chosen to test the additivity of Setschenow constants in high salinity brines. Thiophene has a dipole moment ( $\mu=0.536$ Debye) contrary to fluorene which has a zero dipole moment. The sulfur substitution in the aromatic ring results in a dipole in thiophene. There is no charge separation in fluorene, therefore no dipole moment. Poulson et al., 1999 hypothesized that organic compounds with a dipole moment will have additional interactions with salts in mixed electrolyte systems that could cause the Setschenow Equation to be non-additive. The dipole moment would result in additional ion-ion-dipole interactions that would possibly cause deviations. In addition, the salting-out effect was tested up to an ionic strength of $\sim 5 \mathrm{M}\left(2 \mathrm{M} \mathrm{NaCl}\right.$ and $\left.1 \mathrm{M} \mathrm{CaCl}_{2}\right)$ for thiophene to determine if the Setschenow Equation was additive under these conditions.

The results for both thiophene and fluorene at the lower ionic strengths, $1 \mathrm{M}-3 \mathrm{M}$ ( $\mathrm{Na}-\mathrm{Ca}-\mathrm{Cl}$ ), where the Setschenow Equation is known to be valid in $\mathrm{NaCl}$ and $\mathrm{CaCl}_{2}$ single electrolyte systems, indicates that the Setschenow constants for $\mathrm{NaCl}$ and $\mathrm{CaCl}_{2}$ are additive (Figure 3). This is shown in Figure 3 by plotting both the measured and predicted values characterizing the salting out effect at different ionic strengths tested. The predicted values fall within the standard deviation of the measurements. For thiophene, at $I=5 \mathrm{M}$, the

predicted values for salting-out fall in line with the experimental values (Figure $3 \mathrm{~A}$ ), which was expected because it had log-linear salting-out behavior up to $5 \mathrm{M} \mathrm{NaCl}$ and additive Setschenow constants. This data shows that at least for thiophene the presence of a dipole moment has no effect on the additivity of $\mathrm{NaCl}$ and $\mathrm{CaCl}_{2}$ Setschenow constants. 

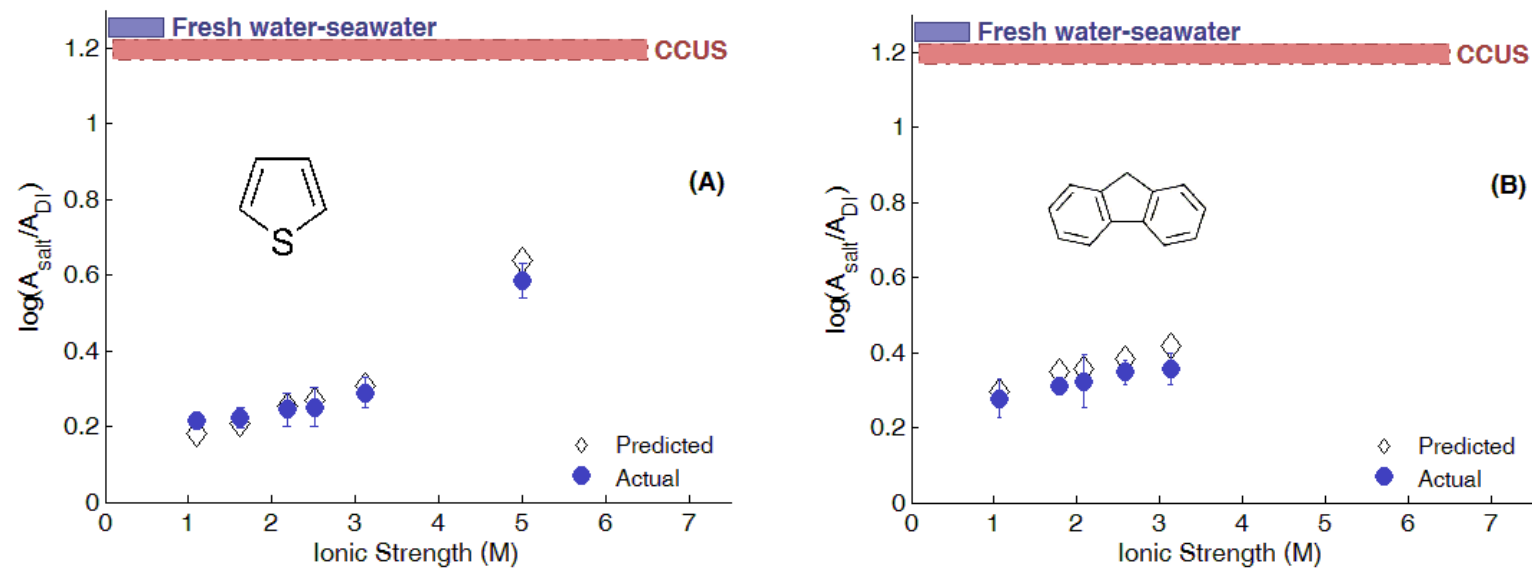

Figure 3. The salting-out effect (i.e. $\log \left(\mathrm{A}_{\text {salt }} / \mathrm{ADI}_{\mathrm{DI}}\right)$ ) of individual organic compounds onto the SPME fiber as a function of ionic strength (M) for A) Thiophene, and B) Fluorene. Colored bars represent salt concentrations for Setschenow constants reported for: Blue bars in seawater; red bars in CCUS $0.1-7 \mathrm{M} I$. The diamonds represent predicted values based on the respective single electrolyte Setschenow constants, and the blue circles (with standard deviations) represent the actual measured values in this study. Triplicate measurements were performed at each ionic strength.

\subsection{Comparison to Models}

The experimental values of $\mathrm{NaCl}$ Setschenow constants determined here were compared to estimates from the published LFERs for these Setschenow constants including one based on log $\mathrm{K}_{\mathrm{ow}}$, and a second based on a pp-LFER (Table 2). These LFERs were developed from solubility data typically taken at lower salt concentration than used in this study. It is noteworthy that naphthalene, fluorene, and phenanthrene were included in the model training set for the $\log \mathrm{K}_{\text {ow }}$ LFER. None of the compounds used in this study were included in the training set for the pp-LFER.

Both the pp-LFER and the log $\mathrm{K}_{\text {ow }}$ LFER (Table 2) predicted $\mathrm{NaCl} \mathrm{K}$ salues that were within $0.04 \mathrm{M}^{-1}$ of the experimental $\mathrm{NaCl}$ Setschenow constants measured here for naphthalene, thiophene, fluorene, and benzothiophene (Table 2). The pp-LFER had higher error for the $\mathrm{NaCl}$ Setschenow constant for phenanthrene, while the log $\mathrm{K}_{\text {ow }}$ LFER had higher error for dibenzothiophene. The root mean square error (RMSE) of the pp-LFER and the log Kow LFER are 0.03 and $0.036 \mathrm{M}^{-1}$, respectively. The best estimates from the log Kow model were for measured values of fluorene and phenanthrene. The pp-LFER underpredicted the $\mathrm{NaCl}$ Setschenow constants for fluorene and phenanthrene. This is likely 
because these PAHs were part of the training set to develop the log Kow LFER, but not the pp-LFER. It appears that both LFERs can provide reasonable predictions of $K_{s}^{i, N a l}$ values for all of these compounds except for dibenzothiophene, but the log Kow LFER is likely to have more accurate predictions for PAHs, due to its training with data from similar compounds.

Table 2. Abraham Solvation Parameters, log $\mathrm{K}_{\mathrm{ow}}$, and $\mathrm{NaCl}$ Setschenow Constant Predictions (Endo et al., 2012; Ni and Yalkowsky, 2003) for the Organic Compounds of Interest in this Study.

\begin{tabular}{|c|c|c|c|c|c|c|c|c|}
\hline Organic Compound & $R_{2}$ & $\pi_{2}$ & $\alpha_{2}$ & $\beta_{2}$ & $V_{x}$ & $\begin{array}{c}\text { pp-LFER } \\
\text { predicted } \\
\mathrm{K}_{\mathrm{s}} \\
\left(\mathrm{M}^{-1}\right)\end{array}$ & $\log K_{\text {ow }}$ & $\begin{array}{c}\log \mathrm{K}_{\mathrm{ow}} \\
\text { predicted } \\
\mathrm{K}_{\mathrm{s}}\left(\mathrm{M}^{-1}\right)\end{array}$ \\
\hline Thiophene & 0.687 & 0.56 & 0 & 0.15 & 0.641 & 0.175 & $\begin{array}{c}1.81 \\
\text { (Johansen and } \\
\text { Pawliszyn, } \\
1996 \text { ) } \\
\end{array}$ & 0.186 \\
\hline Benzothiophene & 1.323 & 0.88 & 0 & 0.2 & 0.982 & 0.209 & $\begin{array}{c}3.17 \\
\text { (Andersson and } \\
\text { Schräder, 1999) }\end{array}$ & 0.241 \\
\hline Dibenzothiophene & 1.959 & 1.31 & 0 & 0.18 & 1.38 & 0.243 & $\begin{array}{c}4.36 \\
\text { (Andersson and } \\
\text { Schräder, 1999) }\end{array}$ & 0.288 \\
\hline Naphthalene & 1.34 & 0.92 & 0 & 0.2 & 1.09 & 0.220 & $\begin{array}{c}3.33 \\
\text { (Schwarzenbach } \\
\text { et al., 2003) }\end{array}$ & 0.247 \\
\hline Fluorene & 1.59 & 1.06 & 0 & 0.25 & 1.36 & 0.256 & $\begin{array}{c}4.32 \\
\text { (Schwarzenbach } \\
\text { et al., 2003) }\end{array}$ & 0.287 \\
\hline Phenanthrene & 2.06 & 1.29 & 0 & 0.29 & 1.45 & 0.250 & $\begin{array}{c}4.57 \\
\text { (Schwarzenbach } \\
\text { et al., 2003) }\end{array}$ & 0.297 \\
\hline
\end{tabular}

The measured $\mathrm{NaCl}$ Setschenow constant for dibenzothiophene, $K_{s}^{i, N a C}=0.213 \pm 0.03 \mathrm{M}^{-}$ 1, was lower than the log Kow LFER predicted value $\left(0.294 \mathrm{M}^{-1}\right)$ or the pp-LFER predicted value $\left(0.243 \mathrm{M}^{-1}\right)$ (Table 2). It was also lower than expected given its high hydrophobicity ( $\log K_{o w}=4.36$ ), and relatively large molar volume. Dibenzothiophene, which was not part of the training set for the log $\mathrm{K}_{\text {ow }}$ model or pp-LFER, also has a lower hydrogen bonding basicity value than the similar thiophenes used in this study, which possibly led to a lower $K_{s}^{i, N a C l}$ than predicted by the log $K_{\text {ow }}$ model or the pp-LFER. The presence of heterocyclic sulfur in between two aromatic rings possibly led to different interactions with the water 
and/or the ions in solution, leading to a lower than expected Setschenow constant. However, this hypothesis needs further investigation.

\subsection{Modeling of $\mathrm{CaCl}_{2}$ and $\mathrm{KCl}$ Setschenow Constants}

$\mathrm{CaCl}_{2}$ is the second most abundant electrolyte after $\mathrm{NaCl}$ in most natural reservoir brines. The paucity of available Setschenow constants for $\mathrm{CaCl}_{2}$ motivated this study to develop a new model that predicts $\mathrm{CaCl}_{2}$ Setschenow constants from $\mathrm{NaCl}$ Setschenow. The developed model uses the experimentally determined $\mathrm{CaCl}_{2}$ Setschenow constants from this study as well as the 19 literature reported Setschenow constants for $\mathrm{CaCl}_{2}$ (Figure 4A). The $\mathrm{CaCl}_{2}$ Setschenow constants estimated here for PAHs and thiophenes adds to a more diverse training set for $\mathrm{CaCl}_{2}$ Setschenow constants for this model. A model for $\mathrm{KCl}$ was also included (Figure $4 B$ ), because, although $\mathrm{K}^{+}$is less abundant in subsurface brines, it is the most studied salt after $\mathrm{NaCl}$ due to its presence in seawater and physiological fluids.

The derived $\mathrm{CaCl}_{2}$ Setschenow constants were systematically greater than the $\mathrm{NaCl}$ Setschenow constants measured in this study. This is consistent with expectation because salting-out effects of cations and anions follow a specific order, known as the Hofmeister series (Cacace et al., 1997), in magnitude of salting out (or in) for organic compounds, gases, and proteins (Jungwirth and Cremer, 2014). This order shows that the salting-out due to $\mathrm{Ca}^{2+}$ will be greater than the salting-out due to $\mathrm{Na}^{+}$, which will be greater than salting-out due to $\mathrm{K}^{+}$. These observations motivated the development of single parameter linear free energy relationships (sp-LFERs) for predicting $\mathrm{CaCl}_{2}$ and $\mathrm{KCl}$ Setschenow constants from $\mathrm{NaCl}$ Setschenow constants.

$$
\begin{array}{cc}
K_{s}^{i, K C}=0.907 K_{s}^{i, N a C}-0.011\left(\mathrm{M}^{-1}\right) & \text { Eqn. } 10 . \\
\left(\mathrm{R}^{2}=0.929, \mathrm{RMSE}=0.024 \mathrm{M}^{-1}, \mathrm{n}=47\right) & \\
K_{s}^{i, C_{C} C_{2}}=1.35 K_{s}^{i, N a C}+0.014\left(\mathrm{M}^{-1}\right) & \text { Eqn. } 11 . \\
\left(\mathrm{R}^{2}=0.79, \mathrm{RMSE}=0.059 \mathrm{M}^{-1}, \mathrm{n}=23\right) &
\end{array}
$$



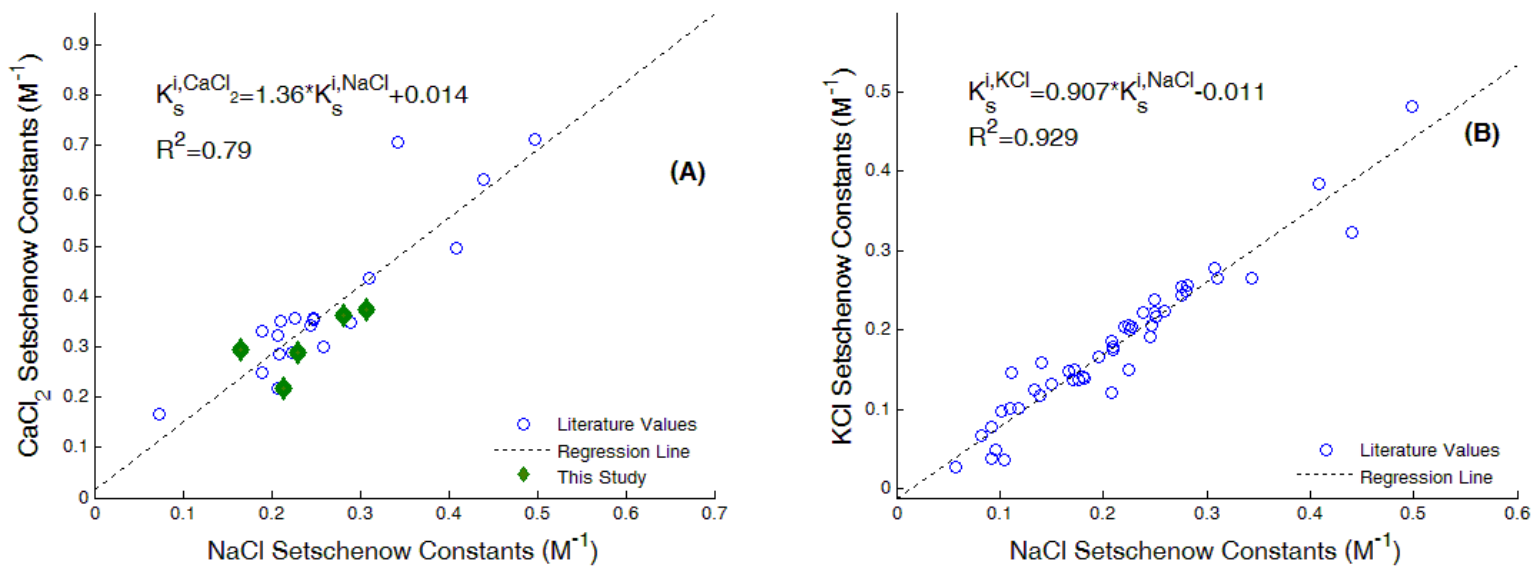

Figure 4. Correlations between the measured A) $\mathrm{CaCl}_{2}$ and $\mathrm{NaCl}$ Setschenow constants and $\mathrm{B}) \mathrm{KCl}$ and $\mathrm{NaCl}$ Setschenow constants. Open blue circles represent the literature values for Setschenow constants and green diamonds represent organic compounds measured in this study. Lines represent model fit, so distance from the line is indicative of error in the model. The outlier on the $\mathrm{CaCl}_{2}$ plot is hexachlorobenzene.

The relative mean standard error (RMSE) for the sp-KCl-LFER (Eqn. 10) is lower than the sp-CaCl 2 -LFER (Eqn. 11), presumably because both $\mathrm{Na}^{+}$and $\mathrm{K}^{+}$are monovalent ions and behave more similarly to each other than a monovalent and divalent cation does. Given the results for $\mathrm{KCl}$ vs. $\mathrm{NaCl}$, we are cautiously optimistic of the extensibility of a spLFER approach to prediction of $\mathrm{K}_{\mathrm{s}}$ of other salt systems. However, the development of these two sp-LFERs are based only on 47 and 23 data points, which is a relatively limited training set. For the sp-KCl-LFER, the range in $\mathrm{NaCl}$ Setschenow constants is $0.057-0.498 \mathrm{M}^{-1}$, which corresponds to a range in $\mathrm{KCl}$ Setschenow constants of $0.028-0.482 \mathrm{M}^{-1}$. For the sp$\mathrm{CaCl}_{2}$-LFER, the range in $\mathrm{NaCl}$ Setschenow constants is $0.074-0.498 \mathrm{M}^{-1}$, which corresponds to a range in $\mathrm{CaCl}_{2}$ Setschenow constants of $0.112-0.712 \mathrm{M}^{-1}$. Lists of the organic compounds used to fit both these linear models are presented in Appendix D. It is recommended that these sp-LFERs only be used in the domain of these models, i.e. the range of salt concentrations and the classes of organic compounds used train the model. Extrapolation outside of this range may be possible, but is currently untested. Classes of organic compounds found in the sp-KCl-LFER include monoraromatic hydrocarbons, PAHs, chlorinated benzenes, furans, dioxins, aromatic acids, ketones, and others, listed in Appendix D. Classes of organic compounds found in the $\mathrm{sp}-\mathrm{CaCl}_{2}$ LFER include 
monoaromatic hydrocarbons, PAHs, chlorinated benzenes, dioxins and furans, and thiophenes. With the inclusion of the data from this study, there is now a more diverse set of compounds in the sp- $\mathrm{CaCl}_{2}$-LFER that was not present before these measurements were completed.

\subsection{Implications}

This study shows that the salting-out effect for all of the hydrophobic organic compounds evaluated here is log-linear up to high concentrations of $\mathrm{NaCl}$ and $\mathrm{CaCl}_{2}$ therefore previously reported $\mathrm{NaCl}$ and $\mathrm{CaCl}_{2}$ Setschenow constants for those compounds at low ionic strength can be used with confidence in the range 2 - $5 \mathrm{M} \mathrm{NaCl}$ and $1.5-2 \mathrm{M}$ $\mathrm{CaCl}_{2}$ to predict aqueous activity coefficients and solubility. Importantly, the Setschenow Equation was found to be additive for thiophene and fluorene in mixed electrolyte brines, typical of oil and gas reservoirs. The previously reported Setschenow constants for naphthalene, fluorene, and phenanthrene all scaled up to $\mathrm{NaCl}$ concentrations up to $5 \mathrm{M}, 2$ $M$, and $3 \mathrm{M}$, respectively. This indicates that Setschenow constants estimated in low salt concentrations can be extrapolated to higher salinities. This is especially important for a variety of CCUS and EOR sites (Burant et al., 2013), such as Sleipner gas field (Portier and Rochelle, 2005), Weyburn EOR site (Emberley et al., 2004), Cranfield demonstration site (Lu et al., 2012), and Frio Formation (Kharaka et al., 2006); all of which can use the Setschenow Equation to predict the aqueous solubility of dissolved organic compounds. In addition, the Setschenow Equation should be capable of predicting the salting-out effect in brine concentrates from many unconventional oil and gas produced waters (e.g. Marcellus Shale), where the median total dissolved solid concentrations are reported around 150,000 $\mathrm{mg} / \mathrm{L}$ (containing around $1.44 \mathrm{M} \mathrm{NaCl}$ and $0.25 \mathrm{M} \mathrm{CaCl}_{2}$ ) (Gregory et al., 2011). The Setschenow Equation can also be used to support assessments of desalination technologies, such as reverse osmosis brines, which have $\mathrm{NaCl}$ concentrations around $1.2 \mathrm{M}$ (TDS of $70,000 \mathrm{mg} / \mathrm{L})$.

While the Setschenow Equation was extended for selected organic compounds here, this does not comprise all organic compounds found in oil and gas reservoirs, and in desalination brines. These organic compounds are representative of small to moderately 
sized hydrophobic organic compounds, including organic compounds with up to three aromatic rings, BTEX compounds, small PAHs and heterocycles. Future work should include determining the validity of the Setschenow Equation for hydrophilic compounds, larger hydrophobic compounds, such as larger PAHs and other larger compounds with four or more rings, and hydrophobic organic compounds with substituents, such as halogenated compounds. It is recommended that the method employed here, the SPME-GC-FID method, should be employed for practicality and sensitivity. However, care must be taken to ensure that compound solubility is not exceeded in the brines.

The use of the LFERs to predict $\mathrm{NaCl}$ and $\mathrm{CaCl}_{2}$ Setschenow constants has important implications for the prediction of solubility of organic compounds in brines. The use of the pp-LFER and/or the log Kow LFER and the sp-LFERs developed in this study allows for the prediction of Setschenow constants for organic compounds in $\mathrm{NaCl}$ and mixed electrolyte solutions ( $\mathrm{NaCl}$ and $\mathrm{CaCl}_{2}$ ), and for $\mathrm{KCl}$, if the organic compound falls into one of the classes of the underlying training set used to derive those models. These LFER models can be incorporated into reactive transport models, such as Subsurface Transport Over Multiple Phases (STOMP) and TOUGH2REACT, to predict aqueous solubility and partitioning coefficients of organic compounds from brines to solids and supercritical $\mathrm{CO}_{2}$, as well as in produced waters from unconventional oil and gas production, and in desalination brines, when the predominant ions in these brines are $\mathrm{Na}^{+}, \mathrm{Ca}^{2+}, \mathrm{K}^{+}$, and $\mathrm{Cl}^{-}$. In the presence of other dissolved species, such as $\mathrm{Mg}^{2+}, \mathrm{SO}_{4}{ }^{2-}, \mathrm{Br}^{-}, \mathrm{Li}^{+}$, and $\mathrm{H}_{2} \mathrm{CO}_{3}(\mathrm{aq})$ and $\mathrm{HCO}_{3}{ }^{-}$, which are usually present in EOR and CCUS sites at relatively higher concentrations, additional models need to be developed to accurately predict aqueous solubility. More aqueous solubility data of organic compounds in the presence of these species is needed for accurate solubility modeling in high salinity sites.

\section{Conclusions}

The salting-out effect for hydrophobic compounds in both this study and the literature in $\mathrm{NaCl}$ and $\mathrm{CaCl}_{2}$ solutions exhibited log-linear behavior up to $2-5 \mathrm{M} \mathrm{NaCl}$ and 1.5 - $2 \mathrm{M} \mathrm{CaCl}_{2}$. This has been shown for BTEX compounds, (Keeley et al., 1991, 1988) as well as the PAHs and sulfur heterocyclics in this study. Fluorene and dibenzothiophene 
displayed log-linear salting-out behavior up to $2 \mathrm{M} \mathrm{NaCl}$, phenanthrene displayed log-linear salting-out behavior up to $3 \mathrm{M} \mathrm{NaCl}$, benzothiophene displayed log-linear salting-out behavior to $4 \mathrm{M} \mathrm{NaCl}$, and naphthalene and thiophene displayed log-linear salting-out behavior up to $5 \mathrm{M} \mathrm{NaCl}$. Fluorene and phenanthrene displayed log-linear salting-out behavior up to $1.5 \mathrm{M} \mathrm{CaCl}_{2}$ and benzothiophene, dibenzothiophene, and thiophene displayed log-linear salting-out behavior up to $2 \mathrm{M} \mathrm{CaCl}_{2}$. This means Setschenow constants measured at low salt concentrations can be extrapolated up to high salt concentrations. This has important implications for measurements and modeling of these constants. Previously measured Setschenow constants (typically measured up to seawater concentrations) can be used up to high $\mathrm{NaCl}$ and $\mathrm{CaCl}_{2}$ concentrations, as well as mixtures of the two. Setschenow constants measured here were found to be additive in Na-Ca brines for fluorene and thiophene. The Setschenow constants of hydrophobic organic compounds with and without a dipole moment should be additive in Na-Ca brines.

In addition, the pp-LFER and log $\mathrm{K}_{\mathrm{ow}}$-LFER were fairly accurate in predicting $\mathrm{NaCl}$ Setschenow constants. The new sp-CaCl -LFER can also be used to predict $\mathrm{CaCl}_{2}$ Setschenow constants from either measured or modeled Setschenow constants. The ppLFER, log Kow LFER, and both sp-LFER models were calibrated with data using $\mathrm{NaCl}$ Setschenow constants measured at low salt concentrations, but that data should be able to be extrapolated up to high $\mathrm{NaCl}$ and $\mathrm{CaCl}_{2}$ concentrations.

\section{Acknowledgements}

This technical effort was performed under the auspice of the US DOE National Energy Technology Laboratory, under the RES contract DE-FE0004000. We thank the Jared and Maureen Cohon Graduate Fellowship in Civil and Environmental Engineering and the Bradford and Diane Smith Fellowship in Engineering for support. Many thanks to Unnati Rao for help with the experiments and Clinton Noack for Matlab help and thorough reviews.

\section{ASSOCIATED CONTENT}

Appendices. 
Contains experimental details about SPME, data defense and removal based on depletions at each salt concentration for each compound and predicted aqueous solubility for each compound based on the Setschenow Equation, data on the organic compounds used in this study, and compounds of interest used in single parameter LFERs.

\section{References}

Andersson, J.T., Schräder, W., 1999. A Method for Measuring 1-Octanol-Water Partition Coefficients. Anal. Chem. 71, 3610-3614. doi:10.1021/ac9902291

Aquan-Yuen, M., Mackay, D., Shiu, W.Y., 1979. Solubility of hexane, phenanthrene, chlorobenzene and p-dichlorobenzene in aqueous electrolyte solutions. J. Chem. Eng. Data 24, 30-34. doi:10.1021/je60080a009

Benko, K.L., Drewes, J.E., 2008. Produced Water in the Western United States: Geographical Distribution, Occurrence, and Composition. Environ. Eng. Sci. 25, 239-246. doi:10.1089/ees.2007.0026

Burant, A., Lowry, G.V., Karamalidis, A.K., 2013. Partitioning behavior of organic contaminants in carbon storage environments: a critical review. Environ. Sci. Technol. 47, 37-54. doi:10.1021/es304262p

Cacace, M.G., Landau, E.M., Ramsden, J.J., 1997. The Hofmeister series: salt and solvent effects on interfacial phenomena. Q. Rev. Biophys. 30, 241-277. doi:10.1017/S0033583597003363

DOE/NETL-2003/119, 2003. U.S. Brine Wells Database.

Eganhouse, R.P., Calder, J.A., 1976. The solubility of medium molecular weight aromatic hydrocarbons and the effects of hydrocarbon co-solutes and salinity. Geochim. Cosmochim. Acta 40, 555-561. doi:http://dx.doi.org/10.1016/0016-7037(76)902234

Eisen, E.O., Joffe, J., 1966. Salt Effects in Liquid-Liquid Equilibria. J. Chem. Eng. Data 11, 480484. doi:10.1021/je60031a007

Emberley, S., Hutcheon, I., Shevalier, M., Durocher, K., Gunter, W.D., Perkins, E.H., 2004. Geochemical monitoring of fluid-rock interaction and $\mathrm{CO} 2$ storage at the Weyburn C02-injection enhanced oil recovery site, Saskatchewan, Canada. Energy 29, 13931401. doi:10.1016/j.energy.2004.03.073 
Endo, S., Pfennigsdorff, A., Goss, K.-U., 2012. Salting-out effect in aqueous $\mathrm{NaCl}$ solutions: trends with size and polarity of solute molecules. Environ. Sci. Technol. 46, 1496-503. doi:10.1021/es203183z

Gordon, J.E., Thorne, R.L., 1967. Salt effects on non-electrolyte activity coefficients in mixed aqueous electrolyte solutions-II. Artificial and natural sea waters. Geochim. Cosmochim. Acta 31, 2433-2443. doi:http://dx.doi.org/10.1016/00167037(67)90013-0

Gordon, J.E., Thorne, R.L., 1967. Salt effects on the activity coefficient of naphthalene in mixed aqueous electrolyte solutions. I. Mixtures of two salts. J. Phys. Chem. 71, 43904399. doi:10.1021/j100872a035

Gregory, K.B., Vidic, R.D., Dzombak, D.A., 2011. Water Management Challenges Associated with the Production of Shale Gas by Hydraulic Fracturing. Elem. 7 , 181-186. doi:10.2113/gselements.7.3.181

Hashimoto, Y., Tokura, K., Kishi, H., Strachan, W.M.J., 1984. Prediction of seawater solubility of aromatic compounds. Chemosphere 13, 881-888.

doi:http://dx.doi.org/10.1016/0045-6535(84)90161-9

Janado, M., Yano, Y., Doi, Y., Sakamoto, H., 1983. Peculiar effects of alkali thiocyanates on the activity coefficients of aromatic hydrocarbons in water. J. Solution Chem. 12, 741-754. doi:10.1007/BF00647385

Jochmann, M.A., Kmiecik, M.P., Schmidt, T.C., 2006. Solid-phase dynamic extraction for the enrichment of polar volatile organic compounds from water. J. Chromatogr. A 1115, 208-16. doi:10.1016/j.chroma.2006.02.061

Johansen, S., Pawliszyn, J., 1996. Trace analysis of hetero aromatic compounds (NSO) in water and polluted groundwater by Solid phase micro-extraction (SPME). J. High Resolut. ... 19, 627-632. doi:http://dx.doi.org/10.1002/jhrc.1240191107

Jonker, M.T.O., Muijs, B., 2010. Using solid phase micro extraction to determine salting-out (Setschenow) constants for hydrophobic organic chemicals. Chemosphere 80, 223227. doi:10.1016/j.chemosphere.2010.04.041

Jungwirth, P., Cremer, P.S., 2014. Beyond Hofmeister. Nat Chem 6, 261-263.

Keeley, D.F., Hoffpauir, M.A., Meriwether, J.R., 1991. Solubility of aromatic hydrocarbons in water and sodium chloride solutions of different ionic strengths: C2-Substituted benzenes. J. Chem. Eng. Data 36, 456-459. doi:10.1021/je00004a032

Keeley, D.F., Hoffpauir, M.A., Meriwether, J.R., 1988. Solubility of aromatic hydrocarbons in water and sodium chloride solutions of different ionic strengths: benzene and toluene. J. Chem. Eng. Data 33, 87-89. doi:10.1021/je00052a006 
Kharaka, Y.K., Cole, D.R., Hovorka, S.D., 2006. Gas-water-rock interactions in Frio Formation following CO2 injection: Implications for the storage of greenhouse gases in sedimentary basins. Geology 34, 577. doi:10.1130/G22357.1

Kharaka, Y.K., Hanor, J.S., 2003. 5.16 - Deep Fluids in the Continents: I. Sedimentary Basins, in: Holland, E.-C.H.D., Turekian, K.K. (Eds.), Treatise on Geochemistry. Pergamon, Oxford, pp. 1-48. doi:10.1016/B0-08-043751-6/05085-4

Lee, L.L., 1997. A molecular theory of Setchenov's salting-out principle and applications in mixed-solvent electrolyte solutions. Fluid Phase Equilib. 131, 67-82. doi:10.1016/S0378-3812(96)03198-6

Long, F.A., McDevit, W.F., 1952. Activity Coefficients of Nonelectrolyte Solutes in Aqueous Salt Solutions. Chem. Rev. 51, 119-169. doi:10.1021/cr60158a004

Lu, J., Kharaka, Y.K., Thordsen, J.J., Horita, J., Karamalidis, A., Griffith, C., Hakala, J.A., Ambats, G., Cole, D.R., Phelps, T.J., Manning, M.A., Cook, P.J., Hovorka, S.D., 2012. C02-rockbrine interactions in Lower Tuscaloosa Formation at Cranfield C02 sequestration site, Mississippi, U.S.A. Chem. Geol. 291, 269-277. doi:10.1016/j.chemgeo.2011.10.020

May, W.E., Wasik, S.P., Freeman, D.H., 1978. Determination of the solubility behavior of some polycyclic aromatic hydrocarbons in water. Anal. Chem. 50, 997-1000. doi:10.1021/ac50029a042

McDevit, W.F., Long, F.A., 1952. The Activity Coefficient of Benzene in Aqueous Salt Solutions. J. Am. Chem. Soc. 74, 1773-1777. doi:10.1021/ja01127a048

Meranda, D., Furter, W.F., 1974. Salt effects on vapor-liquid equilibrium: Some anomalies. AIChE J. 20, 103-108. doi:10.1002/aic.690200113

Monastersky, R., 2013. Seabed scars raise questions over carbon-storage plan. Nature 504, $1-2$.

Ni, N., Yalkowsky, S.H., 2003. Prediction of Setschenow constants. Int. J. Pharm. 254, 167172. doi:10.1016/S0378-5173(03)00008-5

Paul, M.A., 1952. The Solubilities of Naphthalene and Biphenyl in Aqueous Solutions of Electrolytes. J. Am. Chem. Soc. 74, 5274-5277. doi:10.1021/ja01141a011

Portier, S., Rochelle, C., 2005. Modelling CO2 solubility in pure water and NaCl-type waters from 0 to $300^{\circ} \mathrm{C}$ and from 1 to 300 bar. Chem. Geol. 217, 187-199. doi:10.1016/j.chemgeo.2004.12.007

Poulson, S., Harrington, R., Drever, J., 1999. The solubility of toluene in aqueous salt solutions. Talanta 48, 633-641. doi:10.1016/S0039-9140(98)00292-6 
Rossi, S.S., Thomas, W.H., 1981. Solubility behavior of three aromatic hydrocarbons in distilled water and natural seawater. Environ. Sci. \&amp; Technol. 15, 715-716. doi:10.1021/es00088a013

Schwarz, F.P., 1977. Determination of temperature dependence of solubilities of polycyclic aromatic hydrocarbons in aqueous solutions by a fluorescence method. J. Chem. Eng. Data 22, 273-277. doi:10.1021/je60074a010

Schwarzenbach, R.P., Gschwend, P.M., Imboden, D.M., 2003. Environmental Organic Chemistry, 2nd ed. John Wiley \& Sons, Inc., Hoboken, NJ.

Sechenov, M., 1889. Über die Konstitution der Salzlösungen auf Grund ihres Verhaltens zu Kohlensäure. Z. Phys. Chem. 4, 117.

Shaffer, D.L., Arias Chavez, L.H., Ben-Sasson, M., Romero-Vargas Castrillón, S., Yip, N.Y., Elimelech, M., 2013. Desalination and Reuse of High-Salinity Shale Gas Produced Water: Drivers, Technologies, and Future Directions. Environ. Sci. Technol. 47, 95699583. doi:10.1021/es401966e

Sutton, C., Calder, J.A., 1975. Solubility of alkylbenzenes in distilled water and sea water at 25.0.deg. J. Chem. \&amp; Eng. Data 20, 320-322. doi:10.1021/je60066a018

Wang, C., Lei, Y.D., Endo, S., Wania, F., 2014. Measuring and Modeling the Salting-out Effect in Ammonium Sulfate Solutions. Environ. Sci. Technol. 48, 13238-13245. doi:10.1021/es5035602

Whitehouse, B.G., 1985. Observation of abnormal solubility behavior of aromatic hydrocarbons in seawater. Mar. Chem. 17, 277-284. doi:http://dx.doi.org/10.1016/0304-4203(85)90001-5

Whitehouse, B.G., 1984. The effects of temperature and salinity on the aqueous solubility of polynuclear aromatic hydrocarbons. Mar. Chem. 14, 319-332. doi:http://dx.doi.org/10.1016/0304-4203(84)90028-8

Xie, W.-H., Shiu, W.-Y., Mackay, D., 1997. A review of the effect of salts on the solubility of organic compounds in seawater. Mar. Environ. Res. 44, 429-444. doi:10.1016/S01411136(97)00017-2 